\title{
The Impact of a Break-Through Rule on European Firms*
}

\author{
MORTEN BENNEDSEN \\ mb.eco@cbs.dk (http://www.cbs.dk/staff/mortenbennedsen) \\ Department of Economics, Copenhagen Business School and Centre for Economic and Business Research, \\ Denmark

\section{KASPER MEISNER NIELSEN} \\ Centre for Economic and Business Research and Centre for Applied Microeconometrics, University of Copenhagen, \\ Denmark
}

\begin{abstract}
We analyze the impact of a 75 pct. Break-Through rule on 1,035 European firms with dual class shares. In 3-5 pct. of the firms the controlling owners incur a direct loss of control, while in another 11-17 pct. of the firms, the controlling owners are likely to incur a loss of control. Firms in Germany, Italy and the Scandinavian countries are more likely to incur a loss of control. The restrictions that the Break-Through rule put on the ability of these firms to issue new shares to outsiders without changing the control structure are also estimated. We conclude that a significant number of firms with dual class shares in the European Union will be affected by a 75 pct. Break-Through rule.
\end{abstract}

Keywords: takeover regulation, corporate governance, European Union, Break-Through rule, corporate law, dual class shares

JEL Classification: $\quad \mathrm{G} 32, \mathrm{G} 34, \mathrm{G} 38, \mathrm{~K} 12, \mathrm{~K} 22$

\section{Introduction}

The EU initiative on the regulation of takeover bids was initiated by the 1985 White Paper on the completion of the Internal Market, which identified the need for a new company directive. A significant chapter in this ongoing process is the publication in January 2002 of the "Report of the High Level Group of Company Law Experts on Issues related to Takeover Bids", authored by a group of European law professors chaired by Jaap Winter. We will refer to this as the Winter Report throughout this paper. The Winter Report proposed a number of changes in existing company laws throughout Europe, some of which have stirred an intense debate among business communities, interest groups, law makers, economists and law researchers.

In this paper we focus on the impact of only one of these proposals on European firms, namely the introduction of a Break-Through rule, henceforth denoted BT-rule. The BT-rule

*We thank Jonas Herby and Thea M. Dam for excellent research assistance. This project has been supported by CEBR (www.cebr.dk) and the Danish Social Science Research Foundation under the project GOCOW. 
states that an investor, after acquiring a certain threshold of the cash flow rights to a firm, should be able to break through the firm's current control structure. The report suggests that the threshold should be set at 75 pct., so that any owner possessing 75 pct. of the total outstanding shares, independently of differences in voting rights, should have complete control of the firm including the ability to replace management and/or board of directors instantly.

Obviously, a BT-rule affects only the control structures of firms, which have multiple share classes with a different number of votes attached. Therefore many observers have seen this proposal as an attack on controlling owners in firms with dual class shares, a common type of ownership in many European countries (Faccio and Lang, 2002). If controlling owners hold a large fraction of the superior voting shares (SVSs) and a small fraction of limited voting shares (LVSs), it is possible that the introduction of a BT-rule would affect the control structure in the firm. An aggressive outside investor, or even one belonging to the group of controlling owners, may buy enough of the cash flow with limited voting rights to invoke the BT-rule and takeover the firm.

It is, however, worth emphasizing that the impact of a BT-rule on firms with dual class shares will vary depending on how firm ownership is organized; in particular, it depends on the number of outstanding shares, the number of votes attached to each class, the distribution of shares among the group of owners and the threshold level assigned in the BT-rule. Hence, if controlling owners, in addition to their SVSs, possess a large fraction of the LVSs, the impact of a BT-rule will be limited.

The main objective of the present analysis is to identify which firms within the European Union are likely to be affected by a BT-rule. This is done by analyzing the distribution of cash flow and control rights for 1,035 European firms across 10 countries with dual class shares. ${ }^{1}$ Using Sweden as an example, we develop a method to categorize each of the 1,035 firms into four groups, depending on the control structure before and after the introduction of the BT-rule. We show that approximately 3-5 pct. of the firms, located mainly in Denmark, Germany, Italy and Sweden, face a direct loss of control after the introduction of a BT-rule. In these firms there is a single owner or a group of controlling owners possessing at least 50 pct. of the votes but less than 25 pct. of the total outstanding shares.

Focusing on a 50 pct. voting barrier to obtain control of a corporation may be to narrow: many large owners control a corporation with voting shares significant lower than 50 pct. Such controlling owners may also incur a real control loss after the introduction of a BTrule. This is taken into account through a two-step procedure. First, we identify firms that incur a potential control loss, which happens when no single owner (nor the group of large owners ${ }^{2}$ ) possesses 50 pct. or more of the votes and possesses less than 25 pct. of the total cash flow. It is estimated that 45 to 62 pct. of the firms analyzed will face a potential control loss after the introduction of a BT-rule. Among the largest firms in Europe with dual class shares, approximately two thirds of the companies faces a potential loss of control.

Second, we distinguish between firms that are located in the potential control loss group due to a general dispersed ownership structure and firms where control is concentrated and cash flow is dispersed. In our sample, the British and Irish firms fall into the former 
category, whereas firms in Continental Europe and Scandinavia predominate the latter category, indicating that the potential control loss for firms in these countries is likely to be more serious than for similar firms in the UK and Ireland.

The preceding argument is formalized by defining that for the potential control loss to be likely to be realized, firms must have a certain degree of disproportionality between votes and cash flow. Such firms incur a likely control loss. In addition to the group of firms facing a direct control loss, 11 to 17 pct. of the entire sample of firms are likely to incur a control loss. Hence, our main result is that 14 to 22 pct., or 152 to 224 firms, is the maximum number of firms with dual class shares incurring a direct control loss or a likely control loss. Most of these firms are incorporated in Germany, Italy, Scandinavia and—surprisingly—in Great Britain.

We emphasize that our estimate, for the following reasons, is likely to be the maximum number of affected firms: First, there are a number of alternative opportunities for deferring potential takeovers. In general, these opportunities vary significantly due to national corporate laws and national institutions, for example, whether takeover defenses are allowed, the frequency of golden shares in public corporations, the use and scope of shareholder agreements, etc. Because of these alternative opportunities alone, we expect that some of the firms identified as being vulnerable to a BT-rule will in reality be very well protected through other institutional mechanisms that we are unable to describe systematically in this paper. Second, we analyze a "general Break-Through" rule with no exemption for preference shares or other non-voting shares and with no exemption for existing firms. In practice, firms with preference shares or other types of non-voting shares may be excluded from the rule and the political negotiations are likely to result in a grandfather exemption where the BT-rule is applied only to new firms.

We believe our "first step" estimate of the maximum number of firms is valuable for at least two reasons. First, the analysis identifies with certainty a large number of firms (approximately $80 \mathrm{pct}$. of our sample) that will not incur a control loss after the introduction of a BT-rule. Hence, the introduction of a BT-rule will not increase the likelihood of a hostile takeover attempt for these firms. Second, identifying the maximum number of firms that might be affected, while taking into account other potential institutional details that may isolate these firms from hostile takeover attempts, is a useful point of departure for taking a closer look at how vulnerable these firms are.

One likely response to the introduction of a BT-rule is that firms will, if possible, change their ownership structure to avoid any control loss due to a BT-rule (as suggested, for example, by Bebchuck and Hart, 2002; Bolton, 2002; Mayer, 2002). This can have several implications regarding the ability to raise capital by issuing new shares in the open market. Some controlling owners may need to buy up more shares to avoid the consequences of the BT-rule. Other firms may be limited in the amount of new shares they can issue to outsiders without the controlling owner(s) falling short of the threshold value of $25 \mathrm{pct}$. of the outstanding shares. Hence, it is important to know the impact on the ability to raise new capital through share offers. Once again, using Sweden as an example, we develop a categorization of the BT-rule's impact on potential share issues and apply this to the 1,035 EU firms in our sample. We find that a significant number of firms may be affected this way through the introduction of the BT-rule. 
In a recent paper, Berglöf and Burkart (2003) provide a strong theoretically based analysis of the economic impact of the Winter Report, focusing on the BT-rule and the proposed mandatory bid rule. Berglöf and Burkart recognize the need for improvements in European corporate standards; however, they and other commentators (e.g. Bolton, 2002; Mayer, 2002; Pagano, 2002) criticize the whole idea of redesigning corporate governance standards by making changes in the regulation of the takeover process. Other observers (notably Jensen, 2002) have supported the Winter Report arguing that creating a level playing field among European firms is the appropriate way to improve the standard of corporate governance in Europe.

In the present paper our aim is to provide a statistical background that this debate can evolve around. As a result, we do not want to take a particular stand in the debate. Our aim is to develop a categorization system useful for identifying firms affected by corporate policy initiatives directed at firms with dual class shares as well as disproportionality between control and residual income rights. We then apply this system in order to specifically identify firms affected by a 75 pct. BT-rule as suggested in the Winter Report. Most of the debate regarding the introduction of a BT-rule refers to a few prominent cases, such as the Wallenberg controlled Investor AB in Sweden and Telecom Italia in Italy (see Becht, 2002 for a more rigorous case-based study). In the present study we go beyond this handful of cases to do a systematic analysis of almost all European firms with dual class shares. We hope that this identification procedure is useful for both sides in the ongoing debate over the harmonization of European corporate laws.

The intensity of the debate regarding the October 2002 proposal for a new takeover directive meant that the BT-rule was removed from the proposal in early summer 2003. Officially, it is under revision; however, it is not likely that a full BT-rule will be implemented in the near future. We believe the present analysis is still important for at least two reasons: First, the Winter Report had little empirical analysis on the impact of its proposal. It is impossible to evaluate the welfare implications of a given policy proposal without identifying the number of firms expected to be affected by the proposal. Second, it is likely that there may be future proposals in the ongoing process of harmonizing corporate laws within the European Union directed at firms with dual class shares as well as a significant disproportionality between the distribution of control and residual income rights. The categorization system developed in this paper can easily be applied to the analysis of the majority of such future initiatives.

The organization of the rest of the paper is as follows: In the next section we briefly discuss our data set and the distribution of firms with dual class shares in Europe. Section 3 develops our categorization of the impact of a BT-rule using Swedish firms as an example. Section 4 provides the main contribution of the paper, namely, the identification of firms affected by the BT-rule from among all firms with dual class shares in Europe. Section 5 identifies the BT-rule's impact on firms' ability to raise capital by issuing new shares to outside investors. Finally, our findings are discussed in Section 6.

\section{Data}

We combine data from two sources. Most of our data originates from Faccio and Lang (2002), who surveyed the ultimate ownership and control structure in publicly traded 
companies in 15 Western European countries. The data, which was obtained mainly from the countries' stock exchanges and public agencies, provides us with the ultimate ownership for 880 firms with dual class shares from Austria, Finland, France, Ireland, Germany, Italy, Spain and the UK. ${ }^{3}$ As mentioned in the introduction we do not separate between LVSs with zero or a positive amount of votes attached and we also include preference shares into this group. Thus, our sample of firms with dual class shares includes German firms with non-voting preference shares and former state owned French corporations, where the Government separated control from cash flow before privatization.

In addition to this data, we have collected data for all Danish and Swedish firms listed on the stock exchanges in Copenhagen and Stockholm. ${ }^{4}$ We have collected the ultimate ownership distribution for 70 Danish firms and 185 Swedish firms, all of which have dual class shares. ${ }^{5}$ For the record, it should be noted that the data from Faccio and Lang (2002) are from 1996 to 1999, while the data from Denmark and Sweden are from 2001.

The available data on the ultimate owners suit our purpose well because we are interested in both the largest owner and the group of large owners in each firm. However, ultimate owners that have diluted their ownership stake into several holdings below the 5 pct. disclosure level are not included, which means that our analysis slightly underestimates the effects of the BT-rule. ${ }^{6}$

A necessary condition for any impact of a BT-rule on the control structure of a given firm is that there exists disproportionality between the distribution of cash flow and votes. Hence, firms organized according to a one-share-one-vote principle will not be affected. Table 1 shows the presence of dual class shares in $12 \mathrm{EU}$ countries. Table 1 reveals that out

Table 1. Dual class shares.

\begin{tabular}{lccc}
\hline Country & Number of firms & $\begin{array}{c}\text { Number of firms with } \\
\text { dual class shares }\end{array}$ & Share \\
\hline Belgium & 130 & 0 & 0.00 \\
Portugal & 87 & 0 & 0.00 \\
Spain & 632 & 1 & 0.00 \\
France & 607 & 16 & 0.03 \\
Germany & 704 & 124 & 0.18 \\
Austria & 99 & 23 & 0.23 \\
Ireland & 69 & 16 & 0.23 \\
UK & 1,953 & 467 & 0.23 \\
Denmark & $\mathbf{2 1 0}$ & $\mathbf{7 0}$ & $\mathbf{0 . 3 3}$ \\
Italy & 208 & 86 & 0.41 \\
Finland & 129 & 47 & 0.36 \\
Sweden & $\mathbf{3 3 4}$ & $\mathbf{1 8 5}$ & $\mathbf{0 . 5 5}$ \\
Total & 5.162 & 1035 & 0.20 \\
\hline
\end{tabular}

Source: Faccio and Lang (2002). In addition to the data from Faccio and Lang we have collected data for all Danish and Swedish firms from Greens and SIS Ägarservice respectively. 
of the 5,162 publicly traded European firms for which we have information, slightly more than 20 pct. have dual class shares. Thus, dual class shares are a common way to organize corporations in Europe. It is perhaps a bit of a surprise, that the UK is the country with the most firms with dual class shares. Relative to the number of publicly traded firms, the Nordic countries as well as Italy have most dual class shares firms.

\section{A categorization system}

The presence of different voting classes is a necessary but insufficient condition for a BTrule to have any impact on the control structure of a firm. The real impact is determined by the disproportionality between the distribution of votes and the distribution of cash flow rights in a given firm. This disproportionality is determined exclusively by the number of share classes, the relative difference in the number of votes attached to each share class, the distribution of shares across owners within each class and the number of shares in each class.

The above-mentioned information was collected for all firms with dual class shares in Sweden. Thus, in the following section, a subset of 185 Swedish firms with dual class shares is used to develop a categorization system for the impact of a BT-rule on the control structure of Swedish firms. In the next section, this system is applied to our large sample of 1,035 European firms with dual class shares.

There are two benefits involved in using only Swedish firms to develop our categorization system: First, Swedish firms frequently use dual class shares; thus, we expect the BT-rule to have a significant impact. Second, almost all firms with dual class shares in Sweden (174 out of 185) have the following properties: Two classes of shares and SVSs that have 10 times as many votes attached than shares with limited voting rights. This information allows us to illustrate our categorization approach as we have done in figure 1, where Panel A focuses on the single largest owner and Panel B focuses on the group of large owners.

By focusing on the single largest owner, figure 1 reveals the most direct measure of control loss due to the BT-rule. It shows the amount of cash flow internalized by the largest owner in each of the 174 Swedish firms with dual class shares as well as a 10 to 1 voting structure. ${ }^{7}$ The fraction of shares with superior voting rights to the total amount of shares is on the horizontal axis. Thus if a firm like, for example, Holmen $A B$, has three times as many LVSs as SVSs, it will be located at 0.25 on the horizontal axis.

The vertical axis measures the amount of cash flow the largest owner possesses. All 174 firms in figure 1 are plotted using the information on possession of the two share classes. We divide the firms according to whether the largest owner has a majority of the votes or not. In the former case, the firm is plotted with a dot, in the latter with a square in Panel A of figure 1. The largest owner in the above example, Holmen $A B$, possesses 25.1 pct. of the cash flow and 51 pct. of the votes. Thus, Holmen $A B$ is plotted with a dot at 0.25 on the horizontal axis and 0.251 on the vertical axis. Similarly, in the Wallenberg controlled firm, Investor $A B$, the largest owner has 21.4 pct. of the cash flow but less than 50 pct. of the shares, hence Investor $A B$ is represented with a square at 0.407 on the horizontal axis and 0.214 on the vertical axis.

Two lines have also been drawn in figure 1 . The first line denotes the control line, which is the minimum amount of cash flow any owner must internalize to have a majority of the 


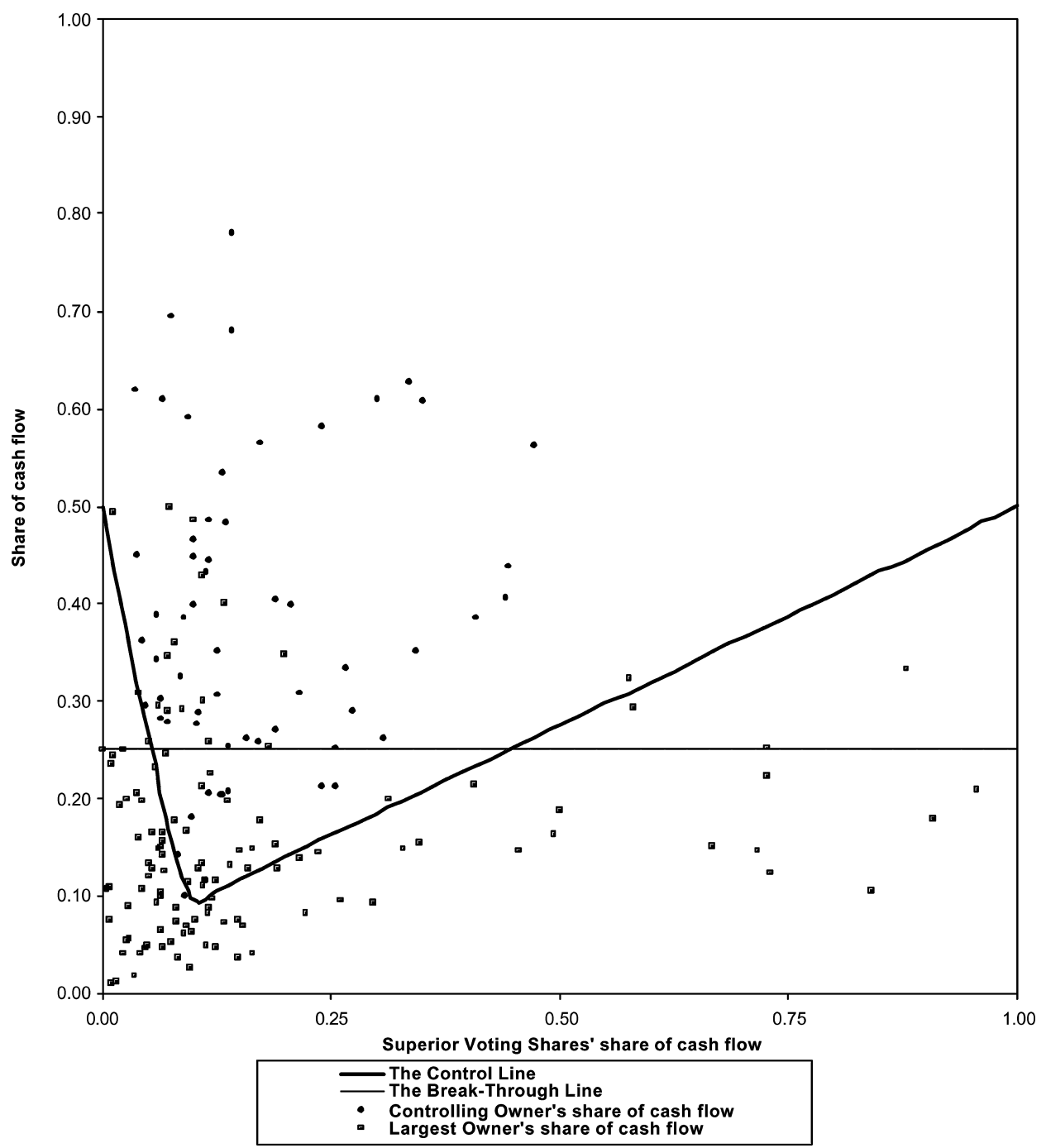

Figure 1. Panel A: Largest owner's share of cash flow in Sweden.

Note: This figure contains all Swedish firms with dual class shares where the voting ratio between SVS (Superior Voting Shares) and LVS (Limited Voting Shares) is 10 to 1 . In total there are 174 firms in the figure. For each firm the SVS' share of the total cash flow is plotted on the horizontal axis. The firms are divided into two groups; those with a controlling owner and those where the largest owner possesses less than 50 percent of the votes. These two groups are marked with a dot and a square respectively and the cash flow of this particular owner is plotted on the vertical axis. The Control Line gives the minimum cash flow necessary to control the firm. The Break-Through Line illustrates the minimum cash flow level that will prevent other owners from breaking through. 


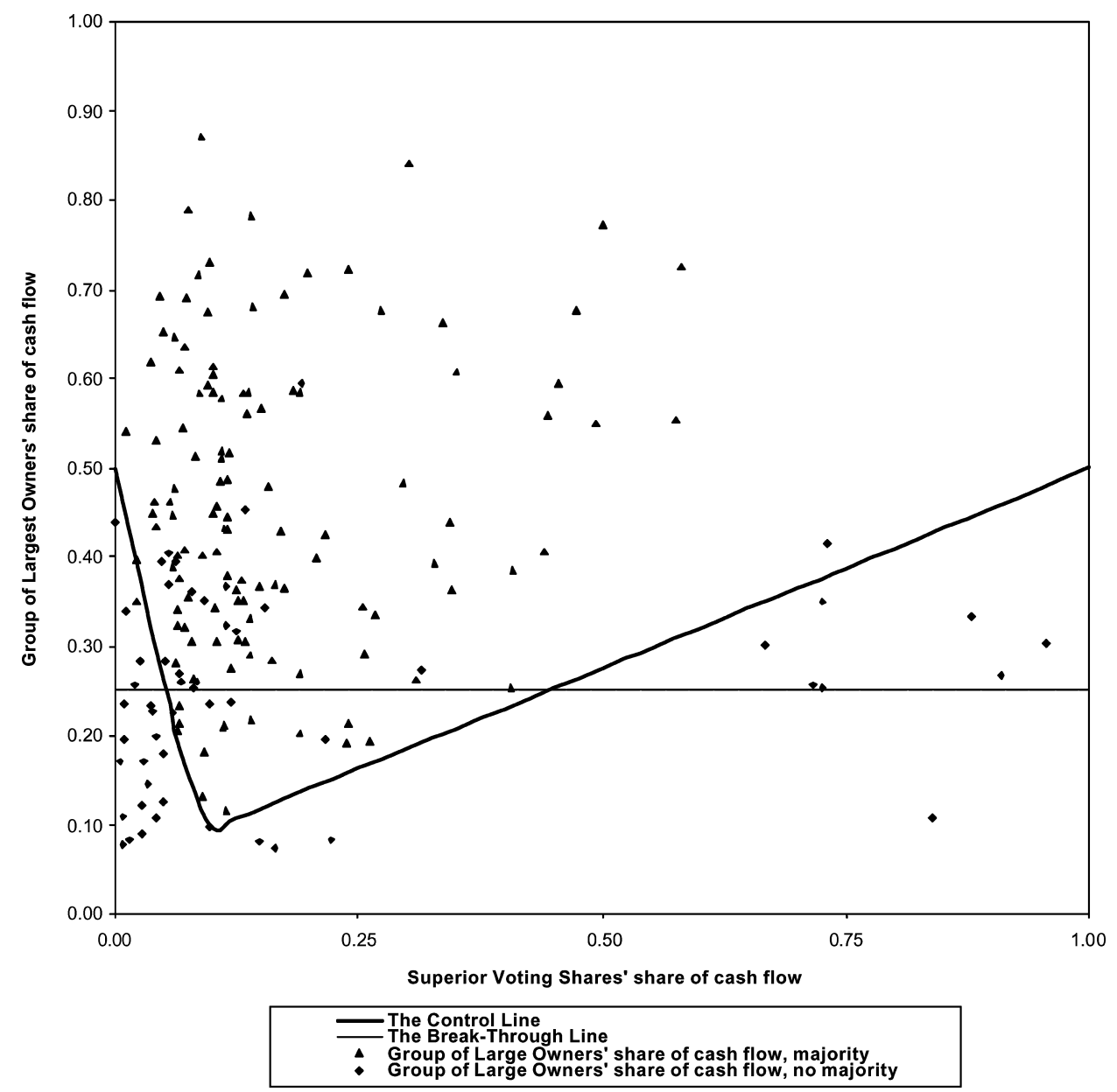

Figure 1. Panel B: Group of largest owners' share of cash flow in Sweden.

Note: This figure contains all Swedish firms with dual class shares where the voting ratio between SVS (Superior Voting Shares) and LVS (Limited Voting Shares) is 10 to 1 . In total there are 174 firms in the figure. For each firm the SVS' share of the total cash flow is plotted on the horizontal axis. The group of largest owners is defined by summing the cash flow and control rights for those owners which hold more than 5 percent of the votes. The firms are divided into two groups; those where the group of large owners possesses a majority and those with a minority, where the group of large owners possesses less than 50 percent of the votes. These two groups are marked with a triangle and a diamond respectively and the cash flow of this particular group is plotted on the vertical axis. The Control Line gives the minimum cash flow necessary to control the firm. The Break-Through Line illustrates the minimum cash flow level that will prevent other owners from breaking through.

votes. We can take, for example, a firm with an equal amount of superior and limited voting shares. Since each SVS has 10 votes relative to the LVS, the minimum amount of shares necessary to obtain a majority of the votes is 55 pct. of the SVSs, which only implies the internalization of 27.5 pct. of the total cash flow. If a firm instead has 10 times as many 
LVSs as SVSs, it is possible to control the firm by owning 95 pct. of the SVSs and, thus, only internalize 9.5 pct. of the cash flow. The control line minimum is reached when the SVSs compose 9.1 pct. of the total cash flow. In firms like this, an owner needs to hold all the SVSs and thereby internalize only 9.1 pct. of the cash flow in order to control the firm. The control line illustrates one of the main implications of organizing a firm with dual class shares; namely, the ability to control a firm by holding a majority of the votes and a smaller amount of the cash flow. Interestingly enough, figure 1 shows that most of the Swedish dual class share firms have chosen a ratio of SVSs to total cash flow of 0.05 to 0.25 . It is indeed in this interval that dual class shares are very effective as a remedy to control a firm with little cash flow.

The second line in figure 1 is the Break-Through line, which we have drawn for a BT-rule of 75 pct. $^{8}$ If a firm is located above this line, there is a single owner who has enough cash flow to block all usage of the BT-rule. On the other hand, for firms below the line, there is no single owner who is able to block the use of the BT-rule in all possible situations.

Our categorization of the impact of the BT-rule follows from the areas defined by the control line and the Break Through line in figure 1. If a firm is located above both lines, there is a single owner possessing enough cash flow to block all usage of the BT-rule. In most, but not all, of these firms the largest owner also possesses a majority of the votes. If this is the case the introduction of the BT-rule has little impact on the controlling owner. Hence, we denote these firms as having comfort with direct control. Fjällräven $A B$ is an example of a comfort with direct control firm since the largest owner has 78.2 and 58.1 pct. of the votes and cash flow respectively. The total number of Swedish firms in this group is $52 .{ }^{9}$

The second group of firms is the "squares" above the BT-rule, i.e. firms where the largest owner possesses more than $25 \mathrm{pct}$. of the cash flow but has less than $50 \mathrm{pct}$. of the votes. In most of these firms the largest owner will be the controlling owner or among the group of controlling owners and the BT-rule will have little impact. For this reason, we denote these firms as having comfort with indirect control. The confectionery producer Coletta Fazer $A B$ belongs to this group because the largest owner has 44.1 pct. of the votes and $34.7 \mathrm{pct}$. of the cash flow and thus enjoys comfort without direct control. In total, there are 24 Swedish firms in this group.

The rest of the firms are situated below the BT-line in figure 1, implying the potential for some kind of control loss. The most direct loss of control happens for the largest owner in the firms with dots in the triangle surrounded by the BT-line and the control line. These firms are characterized by a single owner with a majority of the votes but less than 25 pct. of the cash flow. Before the introduction of the BT-rule, this single owner would have had absolute control of the corporation. However, after the introduction of the BT-rule it is, in principle, possible for an aggressive investor to buy up all outstanding shares that are not in the hands of the controlling owner and apply the BT-rule to take over the corporation. We define these firms as being characterized by a direct control loss. Two examples of Swedish firms that incur a direct control loss due to a 75 pct. BT-rule are Novotek $A B$ and Trelleborg $A B$. It is worth emphasizing that the actual size of the BT-rule has a large impact on the number of firms in this group. For example, the number of firms in this group for a 75 pct. BT-rule is 10, whereas figure 1 shows that lowering the BT threshold to 70 pct (i.e. raising the BT-line in figure 1 to 0.30 ) would increase this group by 12 new firms. 
The final group of firms is the "squares" below the BT-line. These firms are characterized by the largest owner having less than a majority of the votes and less than 25 pct. of the cash flow. Even though we know less about the distribution of control in these firms, it is clear from figure 1 that there is a potential control loss after the introduction of the BT-rule; hence, we define these firms as being characterized by a potential control loss. Two prominent examples of Swedish firms in this group are Volvo $A B$, with a large owner controlling 9.9 pct. of both votes and cash flows, and the bank $S E B A B$. Ninety-nine firms were located in this group.

The group with a potential control loss consists of two kinds of firms: Firms with a dispersed ownership structure, similar to a dispersed one-share-one-vote ownership structure, and firms with a significant disproportionality between cash flow and votes, where the controlling owners exercise their control through implicit or explicit contracts with other owners. It is only the owners of the latter type of firms that are likely to incur a real control loss after the introduction of the BT-rule. Owners in the group of firms with concentrated ownership and potential control loss are likely to incur a control loss after the introduction of the BT-rule. In order to save space, the precise definition of likely control loss is found in the general analysis in the next section.

The premise of figure 1, that the ownership of the largest owner is pivotal for analyzing the impact of the BT-rule, is indeed not met for all corporations. In many firms control is allocated to a group of owners who are tied together by formal or informal agreements. Hence, it may be that the important factor is the amount of control obtained, and the cash flow internalized, by such a group. This idea is captured in Panel B where we illustrate the amount of cash flow internalized by the group of owners with more than $10 \mathrm{pct}$. of the votes in the corporations. This group is interpreted as the group of controlling owners, even though this may not always be the case. The main drawback with this assumption is that such a group does not necessarily have common preferences; indeed, some of the owners with significant voting power can be hostile toward the group of controlling owners. This slants the analysis below, causing an underestimation of the number of firms exposed to the BT-rule because such hostile owners can include their own cash flow stake in an attempt to achieve the 75 pct. threshold level. This bias highlights the importance of a dual analysis of the largest and the group of large owners.

The main difference between Panel A and B in figure 1 is that firms in the latter figure move along the vertical axis if there are several owners with more than $10 \mathrm{pct}$. of the votes. Thus, more firms now lie in the two comfort zones and fewer firms are directly affected by the BT-rule. For instance, the corporation, Investor $A B$, is in the potential control loss group in Panel A because the large owner (the Wallenberg Foundations) possesses 44.1 pct. of the votes. In Panel B, Investor $A B$ is located in the direct control loss group since there is an additional large owner (the BZ Group). The group of controlling owners has more than 50 pct. of the votes, but less than 25 pct. of the cash flow. Panel B in figure 1 reveals that even if we look at the group of large owners, there is still a significant number of firms for which the BT-rule will imply either a direct or an indirect loss of control. There are 14 firms that incur a direct control loss and 27 firms that incur a potential control loss from the introduction of the rule. Thus 21 pct. of the firms in Sweden with dual class shares will either face a direct or potential loss of control due to the BT-rule. 
To sum up, we have established that between 10 and 14 Swedish firms face a direct control loss while between 27 and 99 face a potential control loss after the introduction of a BT-rule. This implies that 22 to 59 pct. of the Swedish firms with dual class shares (or 12 to 33 pct. of all public corporations) potentially may, due to the BT-rule, incur some control-related effects.

\section{European firms affected by the BT-rule}

The categorization system developed in the previous section can be extended to the whole sample of 1,035 European firms with multiple share classes. As mentioned above, a prerequisite for drawing figure 1 was that the ratio of votes between SVSs and LVSs is constant for all firms in each figure. This is the case in all but 11 Swedish firms, but not a general feature across Europe, implying that it is not possible to make similar figures for all the countries in our sample.

Our data, however, contains sufficient information about the distribution of cash flow and votes for all corporations in our sample allowing each firm to be categorized according to the terminology developed in the previous section. Faccio and Lang (2002) collected the distribution of cash flow and votes among the ultimate owners of a corporation, taking into account the number of votes attached to each group of shares. Figure 2 yields the summarized results of this categorization procedure. It divides firms with dual class shares into type of control loss: for each country, for the dual class firms among the top 500 European firms and for the European Union. ${ }^{10}$ The largest firms were drawn from a top-500 list of publicly traded European firms. Of these 500 firms, 104 were in our sample of firms with dual class shares. Panel A in figure 2 shows the distribution of firms according to the largest owner's possession of votes and cash flow, whereas Panel B shows the same information for the group of controlling owners.

Figure 2 provides a number of insights about the impact on European firms of the BT-rule. First, if we look only at the largest owner, approximately 35 pct., or 329 of the European firms with dual class shares, are characterized by having either comfort with direct control or comfort with indirect control. These firms will not be affected directly by the BT-rule because the largest owner possesses at least 25 pct. of the cash flow. Associated British Food PLC, BMW AG, Carlsberg Breweries A/S and Pirelli SPA are among the large European firms in this group. The BT-rule does not increase the likelihood of being taken over since the largest owner has sufficient shares to block any attempt to invoke the BT-rule. It is worth mentioning that in principle these firms can still incur an indirect cost because the BT-rule may limit the amount of cash flow they can sell or limit the firms' ability to raise capital by issuing new shares without affecting the existing control structure. We return to this issue in the subsequent section.

Second, if we look at the group of large owners instead, the share of firms that are in the two comfort zones increases to 52 pct., or 536 firms. Hence, slightly more than half of the firms will not incur a control related cost after the introduction of a BT-rule. As mentioned above, the absence of any direct costs from the BT-rule hinges on the assumption that all large owners wish to keep the current control structure. If one of these owners with a significant cash flow stake supports a takeover initiative, the firm may not be protected anymore. The 


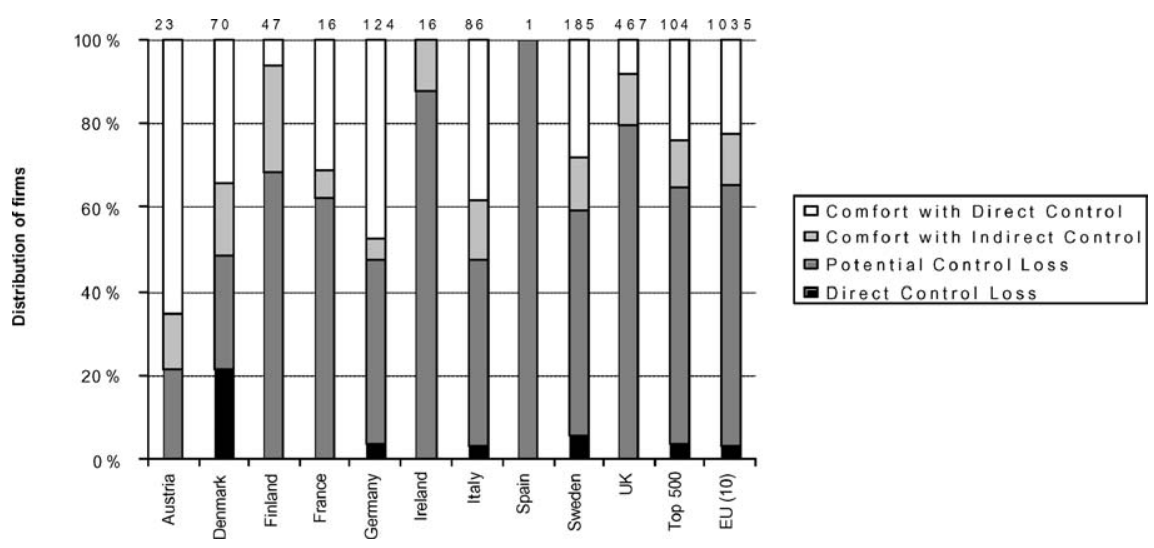

Figure 2. Panel A: The impact of the Break-Through rule on the largest owner.

Note: This figure summarizes the distribution of European firms with dual class shares into four categories in relation to the largest owner and the BT-rule (figure 1, panel A). Direct Control Loss reflects that the controlling owner possesses a majority of the votes, but less than 25 percent of the cash flow. In firms with a Potential Control Loss the largest owner has both less than 50 percent of the votes and 25 percent of the cash flow. Similarly, Comfort with Direct Control and Comfort with Indirect Control consist of firms where the largest owner possesses more than 25 percent of the cash flow. The total number of firms with dual class shares in each country is shown at the top. Top 500 summarizes the distribution of those firms with dual class shares that are among the largest 500 firms in Europe, while $E U(10)$ shows the distribution of firms for all 10 European countries in the analysis.

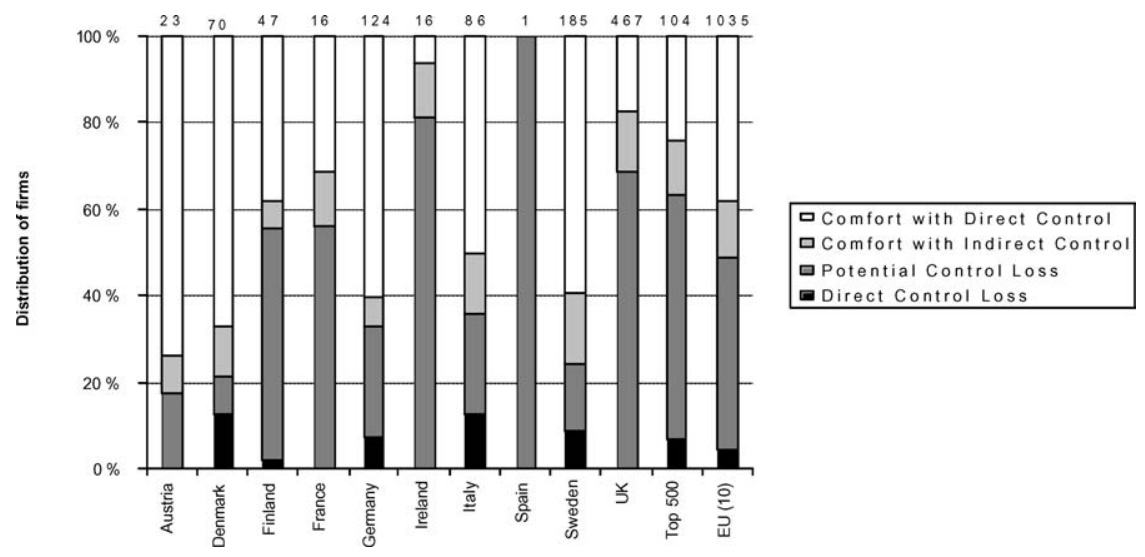

Figure 2. Panel B: The impact of the Break-Through rule on the group of large owners.

Note: This figure summarizes the distribution of European firms with dual class shares into four categories in relation to the group of large owners and the BT-rule (figure 1, panel B). Direct Control Loss reflects that the group of large owners possesses a majority of the votes, but less than 25 percent of the cash flow. In firms with a Potential Control Loss the group has both less than 50 percent of the votes and 25 percent of the cash flow. Similarly, Comfort with Direct Control and Comfort with Indirect Control consist of firms where the group of large owners possesses more than 25 percent of the cash flow. The total number of firms with dual class shares in each country is shown at the top. Top 500 summarizes the distribution of those firms with dual class shares that are among the largest 500 firms in Europe, while $E U(10)$ shows the distribution of firms for all 10 European countries in the analysis. 
German firm Heidelberger Zement AG, the British firms First Choice Holidays PLC and Hammerson PLC as well as the Swedish firm Skanska $A B$ are examples of firms which are not protected when we analyze the largest owner, but are well-protected if all large owners are able to stay together.

Third, the largest owner faces a direct control loss in 3 pct., or 33 firms, including Telecom Italia, Telecom Italia Mobile and Ifil in Italy, ISS in Denmark, Fresenius Medical Care and RWE Aktien-gesellschaft in Germany and finally, the Swedish firms of Kinnevik and Trelleborg. If we focus on the largest European firms, it is interesting to note that there is only a slightly higher fraction of firms (4 pct.) which incur a direct control loss. This indicates that size does not seem to affect which firms incur a control related cost after the introduction of a BT-rule.

Fourth, the number of firms incurring a direct control loss increases to 5 pct., or 45 firms, if we look at the group of large owners. There is a significant country bias since most of these firms are located in Denmark, Germany, Italy and Sweden. There is only one British firm (Harris Philip PLC) in this group when we analyze the group of largest owners (and none if we focus on the largest owner), which may signal that the use of dual class shares is different in the UK than it is in Continental Europe. We return to this issue below.

Finally, 62 pct. or 643 firms, more than half of the firms in our sample, are located in the potential control loss group using the largest owner's ownership stake, while 44 pct., or 456 firms, are located in the potential control loss group if we investigate the group of large owners. These include many large and well-known European corporations such as Diageo, Fiat, Groupe Danone, Shell, Stora Enso and Volkswagen. It is important to restate the existence of two types of ownership structures within this group: Firms with dispersed ownership, but little disproportionality between control and residual income and firms with strong disproportionality between control and cash flow, where the largest owner (or largest owners) do not possess a majority of the votes. In the former case, we do not expect a significant impact from the BT-rule since these firms are similar to firms with a single share class. In the latter type, we expect that, in reality, the largest owner (or the group of large owners) control the firm through formal or informal contracts. For such firms, the BT-rule is likely to have a significant impact and we now provide a method of estimating the number of firms in this likely control loss group.

The distribution of firms between these two types will differ across countries. We expect that the dispersed ownership structure explanation is more prominent in the UK firms than in the Continental European firms within this group. We find some support for this argument by looking at figure 3 , which plots the largest owner's and group of large owners' possession of cash flow against their possession of votes for all firms in the potential control loss group. In Continental European countries such as Italy and Austria and in the Scandinavian countries, we observe a scattered plot with many firms lying significantly above the 45 -degree line. We have estimated the regression line for these scattered plots and added this to figure 3 . Notice that proportionality between cash flow and votes implies a regression line close to the 45degree line, whereas disproportionality implies a regression line above the 45 -degree line. Hence, we see that in Continental European and Scandinavian countries most of the firms with potential control loss have a strong disproportionality. ${ }^{11}$ Thus, control is concentrated in these firms, supporting the argument that there is a real loss of control from a BT-rule 

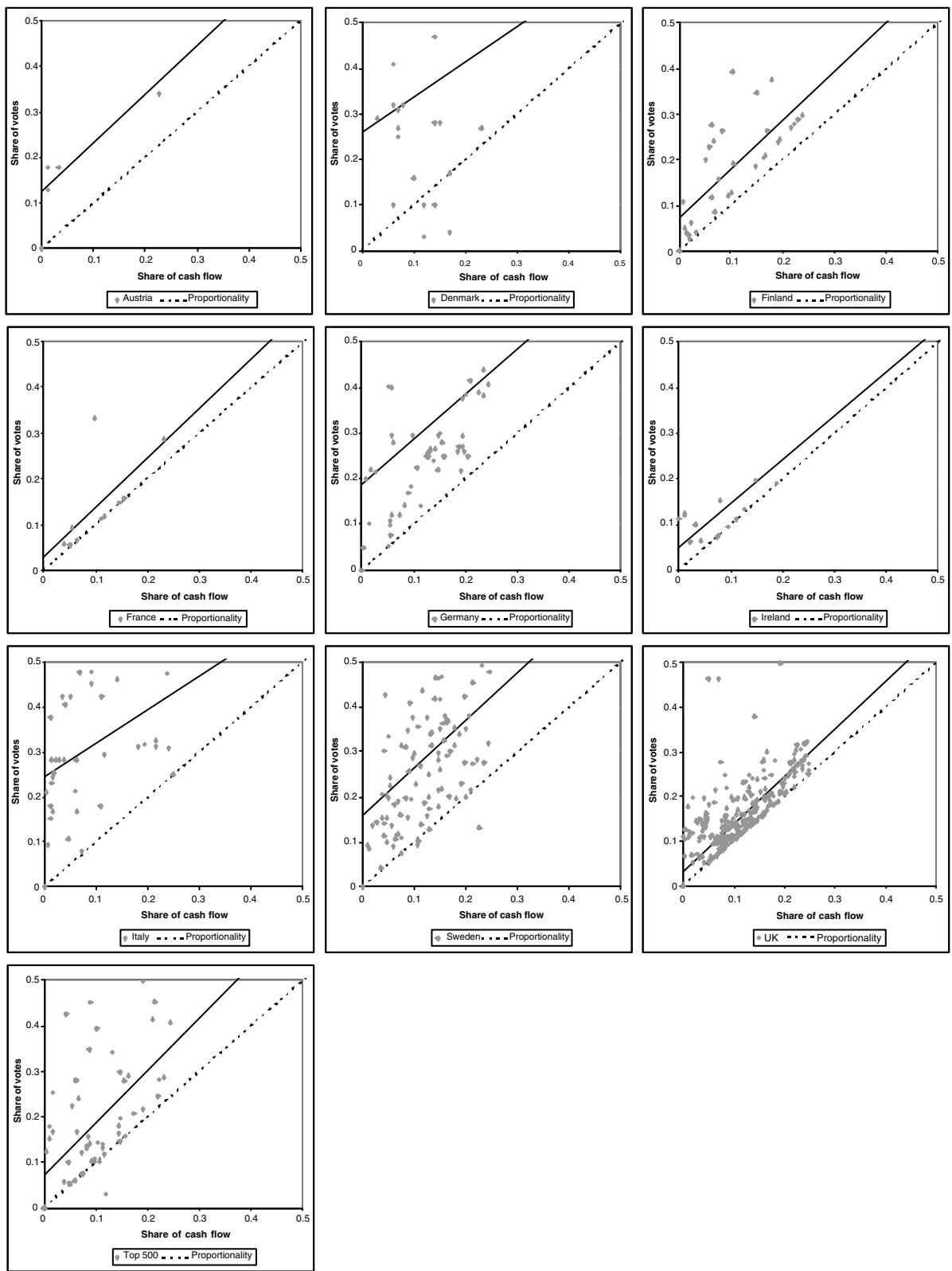

Figure 3. Panel A: Degree of disproportionality in firms with potential control loss, largest owner.

Note: These figures display the largest owner's share of cash flow and votes for firms with a potential control loss (figure 2, Panel A) in each country due to the Break-Through rule. The broken line illustrates proportionality between cash flow and votes, which is present in a one-share-one-vote structure. The degree of disproportionality can be measured by the vertical distance to the proportionality line. Top 500 is comprised by those firms with dual class shares that are among the largest 500 firms in Europe. 

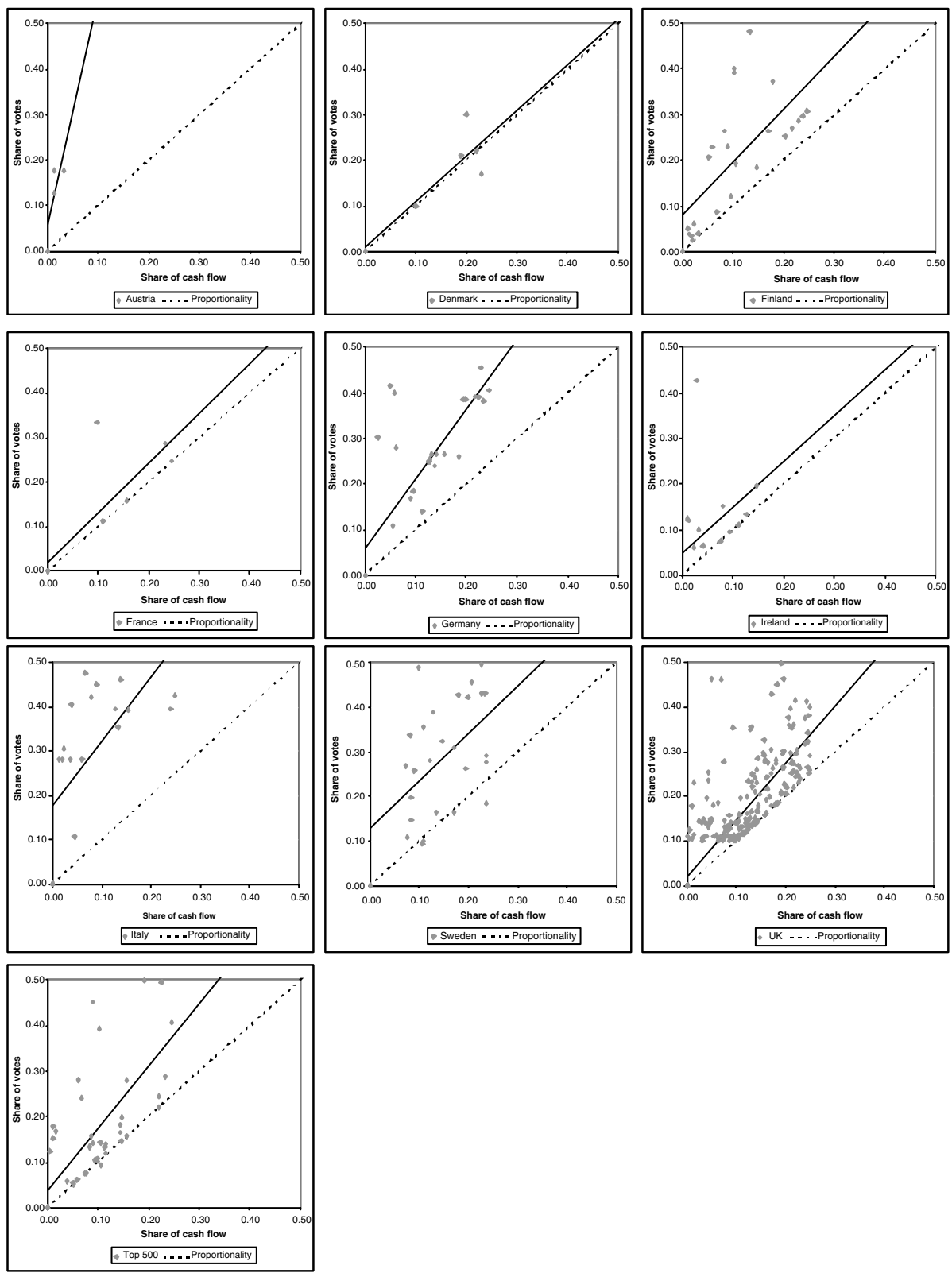

Figure 3. Panel B: Degree of disproportionality in firms with potential control loss, group of large owners.

Note: These figures display the group of large owners' share of cash flow and votes for firms with a potential control loss (figure 2, Panel B) in each country due to the Break-Through rule. The broken line illustrates proportionality between cash flow and votes, which is present in a one-share-one-vote structure. The degree of disproportionality can be measured by the vertical distance to the proportionality line. Top 500 is comprised by those firms with dual class shares that are among the largest 500 firms in Europe. 
since it is likely that the group of large owners in reality has complete control over the corporation before the BT-rule.

The results are quite different for the UK and Ireland. We observe from figure 3 that most firms are located close to or on the 45-degree line and the regression line is not too far from the 45-degree line. This indicates that there is limited disproportionality between cash flow and votes in these countries even in corporations with potential control loss. Hence, for these two countries, firms in general are not in the potential control loss group because there is a group of controlling owners who have little cash flow, but many votes. The ownership structure is frequently dispersed, but there is a significant degree of proportionality between control and residual income. For these reasons we do not expect the BT-rule to have a major impact on the British and Irish firms within this group.

Interestingly enough, figure 3 confirms the traditional view of the difference between the Anglo-Saxon and Continental European model of corporate ownership structure (Shleifer and Vishny, 1997; La Porta, Lopez-de-Silanes and Shleifer, 1999; Barca and Becht, 2001; Gurgler, 2001). In Continental and Scandinavian countries, dual class shares are a remedy to keep control centralized and introduce disproportionality between control and cash flow. In Ireland and the UK, even firms with dual share classes tend to have dispersed ownership, and to have significant, proportionality between control and cash flow.

The preceding arguments can also be applied to remove the firms in the potential control loss group whose owners are likely to incur a real loss of control. Figure 4 depicts the distribution of disproportionality across all firms with potential control loss. We measure the degree of disproportionality as the difference between the amount of votes and cash flow internalized by either the largest owner (Panel A) or the group of largest owners (Panel B). Thus, figure 4 summarizes the more detailed information in figure 3 . We define the group of firms whose owners are likely to incur a control loss as all firms with a disproportionality measure larger than or equal to $10 \mathrm{pct}$. Notice that the relative size of this likely control loss group is significantly larger in Denmark, Germany, Italy and Sweden than in the UK and Ireland, confirming the insight from figure 3. Based on these definitions, we observe in Panel A that 28 pct., or 79 firms in total in the potential control loss group are likely to face a real control loss after the introduction of the BT-rule, for example, Stora Enso, Fiat and Ericsson. On the other hand, large UK firms such as British Airways and Diago are not likely to incur a real loss even though these firms belong to the potential control loss group. The argument is that these firms have diluted control even before the introduction of the BT-rule and that their organization is similar to the organization of firms with a single share class.

It is interesting to notice that 27 out of the 63 larger firms in the potential control loss group are also in the likely control loss group. Thus the share of larger firms that are likely to face a real control loss within the potential control loss group is larger than the share of small and medium firms. This indicates that a significant number of the European top-500 firms will be affected by the BT-rule.

Figure 4, Panel B provides the distribution of disproportionality among the potential control loss firms focusing on the group of largest owners. We notice that 26 pct., or 119 out of the 456 firms in the potential control loss group are likely to actually realize this cost. Notice that the share of larger firms that are likely to face a real control loss within the potential control loss group is now almost the same as the share of small and medium firms. 


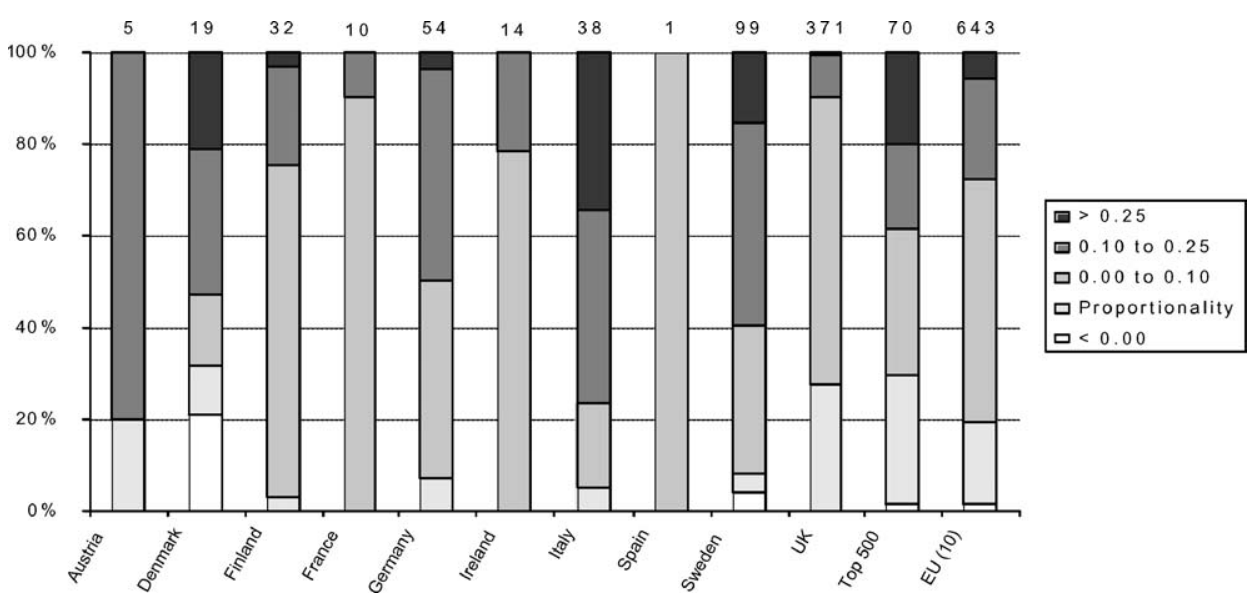

Figure 4. Panel A: Degree of disproportionality in firms with a potential control loss, largest owner.

Note: This figure summarizes the distribution of European firms with a potential control loss (figure 2, Panel A) into five categories in relation to the degree of disproportionality, defined as the difference between the largest owner's share of votes and cash flow. Proportionality reflects a situation where the largest owner's share of votes equals the share of cash flow. This figure summarizes the distribution of firms in figure 3, Panel A, where the degree of disproportionality is given by the vertical distance to the proportionality line. Top 500 summarizes the distribution of those firms with dual class shares that are among the largest 500 firms in Europe, while $E U(10)$ shows the distribution of firms for all 10 European countries in the analysis.

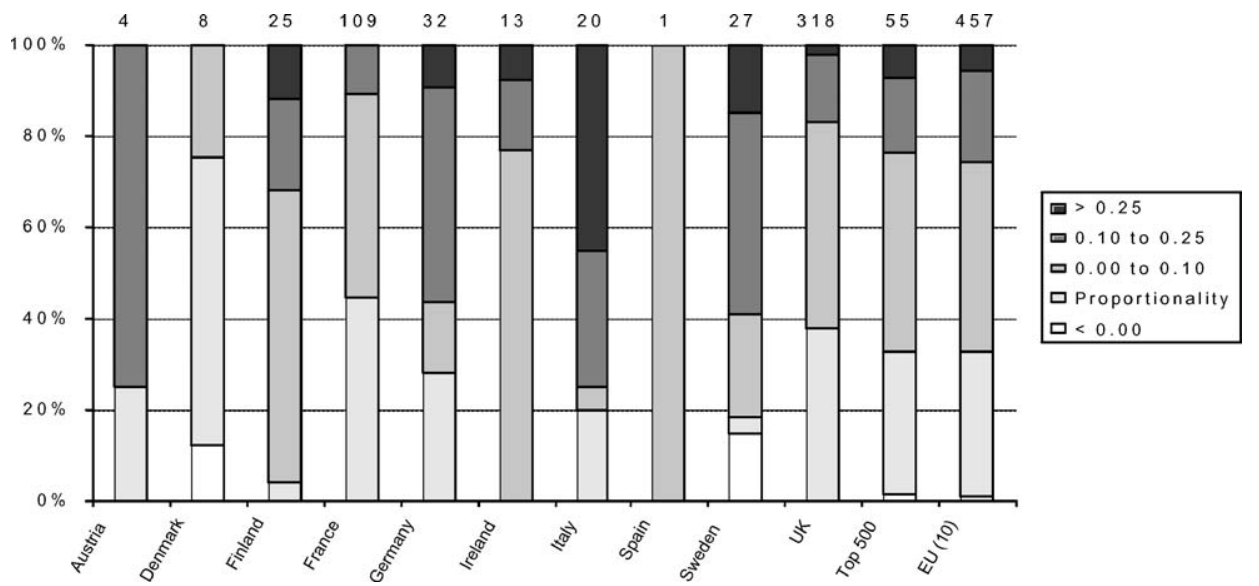

Figure 4. Panel B: Degree of disproportionality in firms with a potential control loss, group of large owners.

Note: This figure summarizes the distribution of European firms with a potential control loss (figure 2, Panel B) into five categories in relation to the degree of disproportionality, defined as the difference between the group of large owners' share of votes and cash flow. Proportionality reflects a situation where the group of large owners' share of votes equals the share of cash flow. This figure summarizes the distribution of firms in figure 3, Panel $\mathrm{B}$, where the degree of disproportionality is given by the vertical distance to the proportionality line. Top 500 summarizes the distribution of those firms with dual class shares that are among the largest 500 firms in Europe, while $E U(10)$ shows the distribution of firms for all 10 European countries in the analysis. 


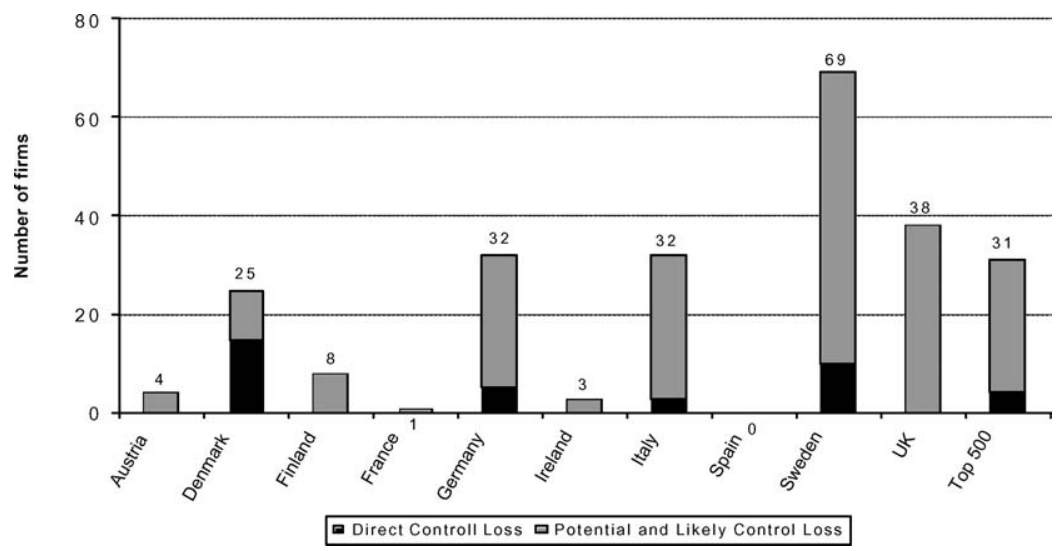

Figure 5. Panel A: The impact of the Break-Through rule, number of firms where the largest owner faces a direct or potential and likely control loss.

Note: This figure shows the number of companies where the largest owner faces a direct or a potential and likely loss of control. Top 500 summarizes the distribution of those firms with dual class shares that are among the largest 500 firms in Europe. The total number of firms with either a direct or potential and likely control loss is displayed on top of each bar.

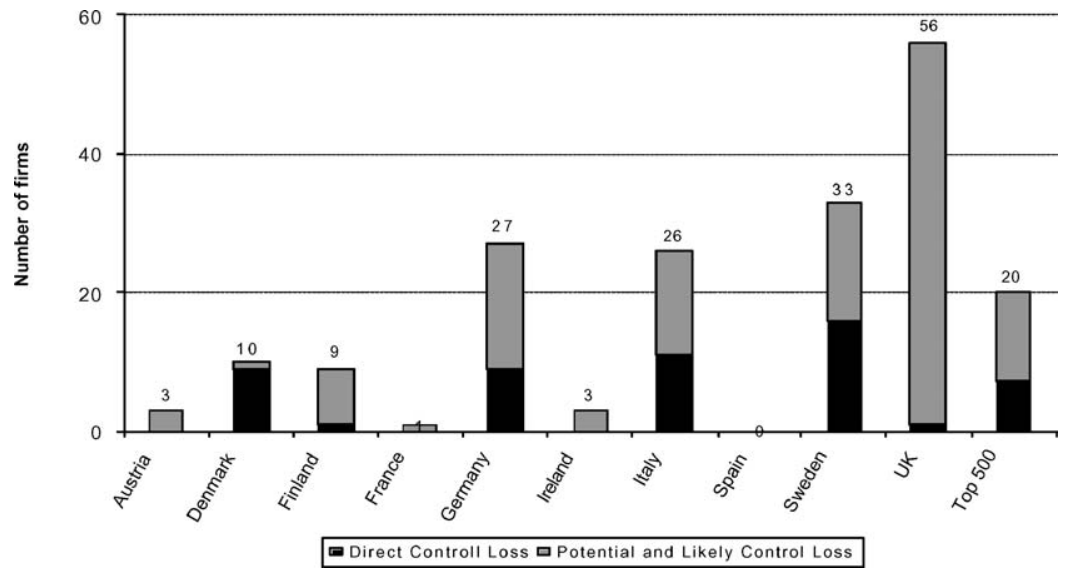

Figure 5. Panel B: The impact of the Break-Through rule, number of firms where the group of large owner faces a direct or potential and likely control loss.

Note: This figure shows the number of companies where the group of large owners face a direct or a potential and likely loss of control. Top 500 summarizes the distribution of those firms with dual class shares that are among the largest 500 firms in Europe. The total number of firms with either a direct or potential and likely control loss is displayed on top of each bar.

Figure 5, which summarizes the main findings of the present paper, depicts the actual number of firms that have been identified as incurring a direct or likely control loss. We find that somewhere between 166 (16 pct.) and 212 (20 pct.) firms, depending on whether we focus on the largest owner or the group of largest owners, are categorized into these 
two groups. These numbers are our best estimate of the actual number of European firms affected through their control structure by the proposed 75 pct. BT-rule. ${ }^{12}$

Focusing on control loss related to the largest owner, we observe in Panel A, in figure 5 that 212 firms are likely to be affected by the rule. There is a significant variation across countries: Sweden has 69 firms that incur either a direct control loss or are likely to incur such a loss. Sweden is the country most affected by the BT-rule both with respect to the absolute number of firms and relative to the number of incorporated firms. Other countries with many affected firms include Denmark, Germany, Italy and the United Kingdom. It is worth mentioning that our conclusion regarding British firms is moderated by at least two factors: First, none of the British firms are in the direct control loss group, thus the impact of the BT-rule is sensitive to the way we have defined likely control loss. Second, the UK is by far the European country with the most incorporated firms, thus the fraction of affected firms relative to the number of incorporated firms is smaller in the UK than in Denmark, Germany, Italy and Sweden.

Panel B in figure 5 focuses on the group of large owners. We see that the illustration in figure 5 is similar to Panel A. In total, we identify 166 firms among the 1,035 firms with dual class shares, which will be affected by the rule even if the group of large owners can stay together. The country variation in Panel B does not deviate significantly from the country variation in Panel A; most of the affected firms are incorporated in Germany, Italy, the Scandinavia and the UK.

When we focus on the largest owner, we identify 31 firms among the 104 top-500 firms in Europe that face a direct or a likely control loss from the BT-rule, for example, Groupe Danone, Heidelberger Zement, SAP, Stora Enso and Telecom Italia. When the group of large owners can remain together, this number falls to 20 , as is the case with Ifil, Fiat, Fresenius, Mesträ-Serla and Pirelli.

As a robustness check we also included firms with a disproportionality measure between 5 and 10 pct. This increased the number of affected firms to 193 if we analyze the group of largest owners and to 284 if we analyze the largest owner. The only significant difference on the country level is that more British firms are affected.

We sum up this section by emphasizing our main findings. We believe that the owners of at least 3-5 pct., or 33 to 47 of the European firms with dual class shares, will incur a direct loss of control after the introduction of a 75 pct. BT-rule. In addition, we find that the owners of an additional 11-17 pct., or 119 to 179 of the firms are likely to incur a control loss. Furthermore, the significance of the BT-rule differs across countries, with firms in Germany, Italy and the Scandinavian countries being most vulnerable. In addition, a significant number of British firms with dual class shares have the potential to be affected even though the more dispersed ownership structure in these firms may reduce the actual impact.

\section{The impact on firms' ability to raise capital via the stock market}

Changing the regulatory regime in which European corporations work will most likely affect the organization of these firms. Several commentators (e.g. Bebchuck and Hart, 2002; Berglöf and Burkart, 2003; Bolton, 2002) have suggested, for instance, that some firms affected by the BT-rule can reorganize themselves using pyramidal structures to keep 
the current control distribution, and other firms may choose to incorporate in a country outside the European Union. An alternative and less drastic response from the affected firms in the direct or potential control loss areas of figures 1 and 2 above would be that controlling shareholders buy up cash-flow until they reach the 25 pct. threshold.

In addition to some owners buying up shares, the BT-rule is likely to limit the willingness of corporations to raise capital by issuing new shares to investors outside the controlling group of owners. Thus, it is likely that firms vulnerable to the BT-rule will abstain from issuing shares and rely on other, more expensive sources of capital.

We analyze these two questions simultaneously in the following. We assume that the corporations can issue only non-voting shares. Allowing for the sale of voting shares may affect the control structure too. This effect, however, would happen independently of the BT-rule, supporting our assumption about issuing non-voting shares only.

We estimate the firms' ability to raise capital by issuing shares to outsiders without falling short of the $25 \mathrm{pct}$. threshold. It is measured in percentages of the current outstanding shares to capture the fact that small firms often need a smaller amount of new capital. The specific formula we apply is CF/0.25 - 1, where CF stands for the largest owner's (or group of largest owners') share of cash flow. Notice that this measure can be either positive or negative. A negative number implies that the largest owner(s) currently possesses less than $25 \mathrm{pct}$. of the cash flow, and therefore must buy up shares to avoid the control loss induced by the BT-rule.

Figure 6 shows the possible issue of non-voting shares without changing the present control structure focusing on the largest owner. The results vary significantly across countries in the European Union. Countries like Austria, Germany and Italy have a large proportion of firms in the positive range, whereas the UK and Ireland have the most firms in the negative, which is consistent with these countries having many firms with a dispersed ownership structure.

Notice that, in general, there are few firms in the interval $(-10,10)$ pct., which we define as the relevant range for most large owners with an intention of changing the capital structure of a given firm. This supports the conclusion that changing capital structure in response to the introduction of a BT-rule may be an attractive option for only a small number of firms. Bang \& Olufson A/S, Fiskars OVI, Groupe Danone SA, Dredsner Bank AG, Volkswagen $A G$, Telecom Italia SPA, Allied Domecq PLC and Cadbury Schweppes PLC are examples of the relatively few firms located in the $(-10,10)$ pct. range.

Returning to the group of large owners in Panel B, we observe that approximately half of all firms can significantly expand their cash flow without affecting the current control structure. Large corporations like BMW AG, Airitalia SPA, Saab AB and Royal \& Sun Alliance Insurance PLC are able to expand their cash flow by at least 100 pct. without a contribution from the coalition of controlling owners.

As emphasized above, many firms will be in the negative area due to a dispersed ownership structure. Figure 7 analyzes the impact on capital structure where we have removed all firms with a disproportionality less than 10 pct. for either the largest owner (Panel A) or the group of largest owners (Panel B). Focusing on the largest owner leaves us with 230 firms. There are 32 of these that are located in the $(-10 ;+10)$ pct. range. This is a realistic estimate on the number of firms that will choose not to issue shares to outsiders or whose controlling owner may try to buy up shares. This is a small number and it is sensitive to the method 


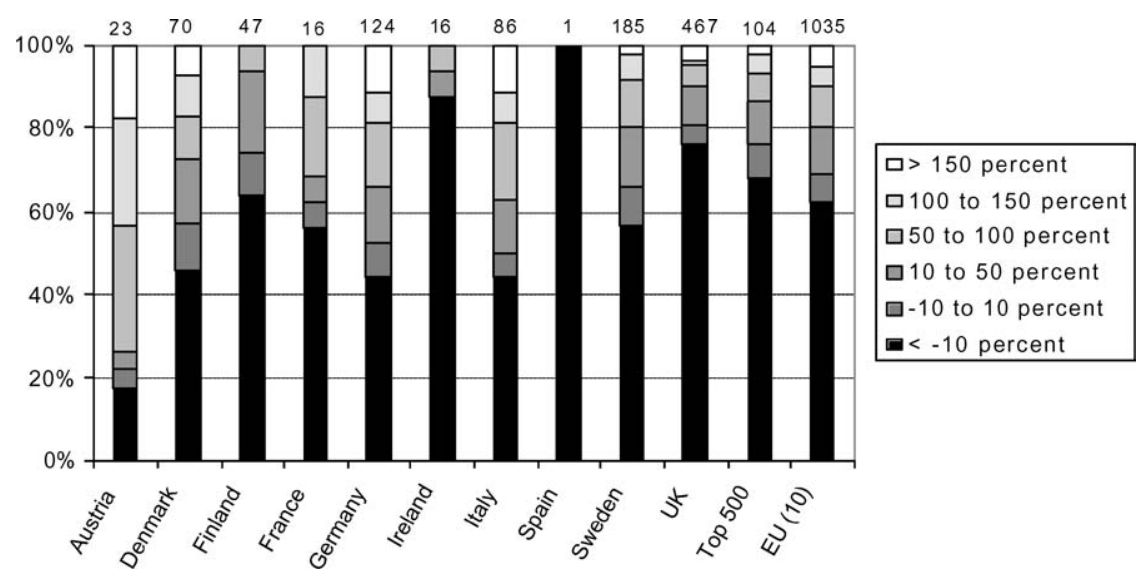

Figure 6. Panel A: The impact of the Break-Through rule on the maximum amount of cash flow that can be issued to outside investors without changing the present control structure, largest owner.

Note: This figure summarises the distribution of European firms with dual class shares into 6 categories reflecting the maximum amount of cash flow that can be issued to outside investors without changing the present control structure. Positive numbers show how much the cash flow can be extended without reducing the largest owner's share below the threshold of the Break-Through rule. Negative numbers reflect a situation where the present largest owner does not offset the Break-Through rule. Top 500 summarizes the distribution of those firms with dual class shares that are among the largest 500 firms in Europe, while $E U(10)$ shows the distribution of firms for all 10 European countries in the analysis.

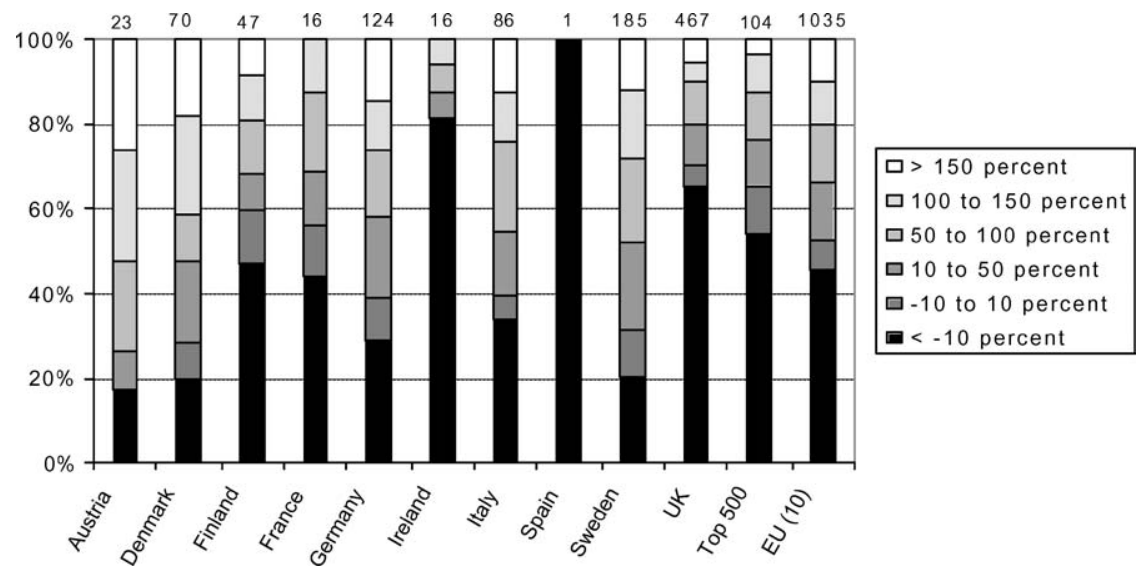

Figure 6. Panel B: The impact of the Break-Through rule on the maximum amount of cash flow that can be issued to outside investors without changing the present control structure, group of large owners.

Note: This figure summarises the distribution of European firms with dual class shares into 6 categories reflecting the maximum amount of cash flow that can be issued to outside investors without changing the present control structure. Positive numbers show how much the cash flow can be extended without reducing the group of large owners' share below the threshold of the Break-Through rule. Negative numbers reflect a situation where the present group of large owners does not offset the Break-Through rule. Top 500 summarizes the distribution of those firms with dual class shares that are among the largest 500 firms in Europe, while $E U(10)$ shows the distribution of firms for all 10 European countries in the analysis. 


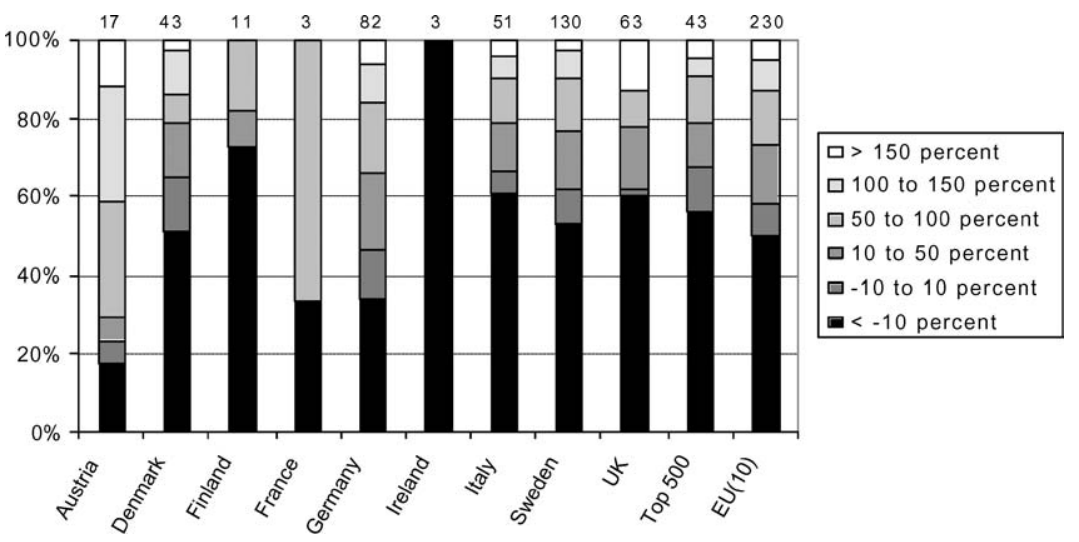

Figure 7. Panel A: The impact of the Break-Through rule on the maximum amount of cash flow that can be issued to outside investors without changing the present control structure, largest owner with disproportionality $>10$ percent.

Note: This figure summarises the distribution of European firms with dual class shares and disproportionality larger than 10 percent into 6 categories reflecting the maximum amount of cash flow that can be issued to outside investors without changing the present control structure. Positive numbers show how much the cash flow can be extended without reducing the largest owner's share below the threshold of the Break-Through rule. Negative numbers reflect a situation where the present largest owner does not offset the Break-Through rule. Top 500 summarizes the distribution of those firms with dual class shares that are among the largest 500 firms in Europe, while $E U(10)$ shows the distribution of firms for all 10 European countries in the analysis.

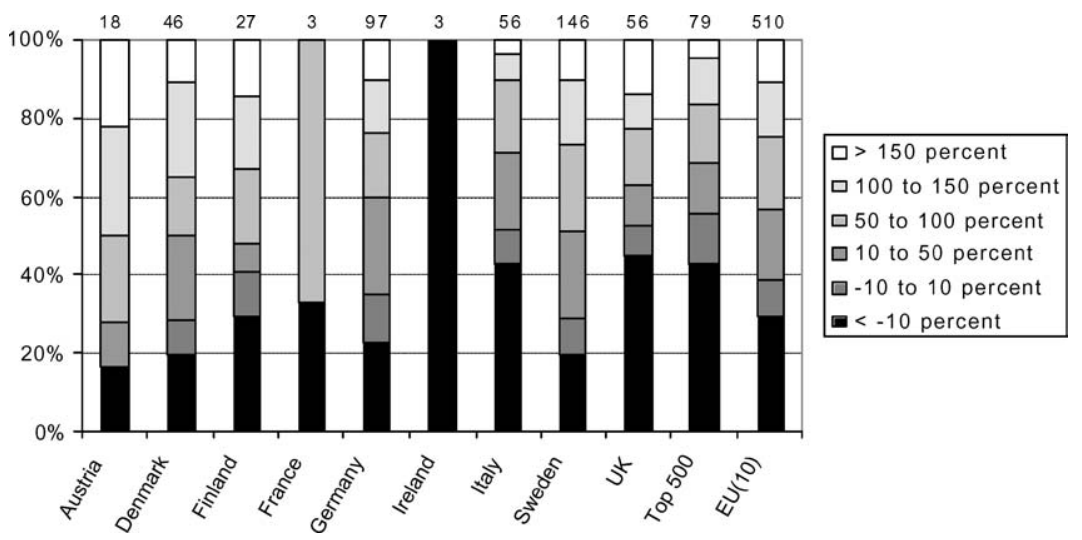

Figure 7. Panel B: The impact of the Break-Through rule on the maximum amount of cash flow that can be issued to outside investors without changing the present control structure, group of large owners with disproportionality $>10$ percent.

Note: This figure summarises the distribution of European firms with dual class shares and disproportionality larger than 10 percent into 6 categories reflecting the maximum amount of cash flow that can be issued to outside investors without changing the present control structure. Positive numbers show how much the cash flow can be extended without reducing the group of large owners' share below the threshold of the Break-Through rule. Negative numbers reflect a situation where the present group of owners does not offset the Break-Through rule. Top 500 summarizes the distribution of those firms with dual class shares that are among the largest 500 firms in Europe, while $E U(10)$ shows the distribution of firms for all 10 European countries in the analysis. 
we have applied. If we instead include all firms with a disproportionality larger than 5 pct., it increases the number of firms in this range to 46. Panel B focuses on the group of large owners. With a 10 pct. disproportionality cutoff level we observe that 46 firms are located in the $(-10 ;+10)$ pct. range. Again, this is a relatively small number. If we instead use the 5 pct. cutoff level on the measure of disproportionality, the number of firms likely to be affected is 56 .

From the present analysis we can conclude that a significant number of firms are likely to either use more expensive alternative sources of capital or buy up own shares to neutralize the effect of a BT-rule. There is one important caveat to this conclusion. We have identified firms which may have an incentive to change capital structure if they are below the BTrule's threshold value and not to issue shares if they are above it. However, many old well-established firms do not use the stock market to raise capital. Thus, it is likely that some of the firms we have identified even in the absence of a BT-rule would use other channels to raise capital. This may imply that the real number of firms incurring a capital related cost from the BT-rule is smaller than we have found.

\section{Discussion}

The BT-proposal has been controversial and raised much discussion among lawyers and economists. In the present paper, we have tried to qualify this debate through a systematic investigation of which European firms are likely to be affected by the BT-rule. The Winter Report's motivation for this rule is that it will level the playing field and thereby increase outside pressure on corporations. More outside pressure will then result in an improved standard of corporate governance to the benefit of the European Community.

Even though the intensive debate following the Winter Report has implied that the BTrule is not likely to be implemented in the near future, it is still important to understand the empirical consequences of introducing such a rule in Europe. This is mainly because it is likely that there will be future proposals in the ongoing harmonization process directed at firms with dual class shares and a significant disproportionality between the distribution of control and residual income rights.

We have shown that the controlling owners in 3-5 pct., or 33 to 47 of the 1,035 firms with dual class shares, incur a direct loss of control due to the BT-rule. In addition to this direct control loss, we expect that the controlling owners in 11-17 pct. of the corporations are likely to face a control related loss. These firms are in particular incorporated in Denmark, Finland, Germany, Italy, Sweden and the United Kingdom. Between 20 and 31 of these firms belong to the group of largest European firms. On the basis of these findings we draw our main conclusion; a significant number of the European firms with dual class shares are likely to be affected by the BT-rule.

It is important to emphasize that our results do not as such imply that the rule is good or bad for the European Community. Proponents may argue that the desired mobility of corporate control and the implied effects on corporate governance will only be achieved if there are a significant number of firms affected by the rule. If the general organization of firms implies that most owners were in the comfort zones (to use the language of figure 2), the proposal would have little impact and, therefore, be redundant. 
Similarly, opponents of the proposal may be seriously concerned with the number of firms affected as well as with the fact that many well-run, large European firms appear to be among the vulnerable corporations. It is likely that these firms will reorganize themselves to avoid the impact of the BT-rule. We have shown that buying up cash flow to neutralize the rule is a realistic choice for only a few firms. Hence, in an attempt to neutralize the BTrule's impact, we can expect many other firms to reorganize the ownership structure through pyramidal schemes or to incorporate in countries outside the European Union. Of course, all such activities are expected to be costly, in addition to working against the intention of the BT-rule.

It is important to reiterate that our estimate is most likely an upper boundary for the actual number of firms affected. First, firms may have other takeover defenses that isolate them from a more active market for corporate control. Second, the proposal that eventually may come out of the political process in the EU commission is likely to be less general than the one we have analyzed here. For instance, preference shares, and most likely all other types of non-voting shares, may be excluded from the rule. This would significantly reduce the number of firms affected. Finally, it may also be that the future rule will include a "grandfather" clause which restricts the rule to firms that are incorporated and listed after the rule has been put into force. In that case, the rule would not affect any of the firms we are analyzing in this study.

An interesting question worth looking at is whether owners are entitled to compensation due to loss of control. This question has two aspects: First, deciding whether a loss of control legally entitles an owner to being compensated and second, estimating the size of any individual owner's loss of control should compensation be given. The former aspect is likely to be determined by the European or national courts. In the event that compensation is given, the individual firm's actual or likely loss must be the basis for defining the size of a potential compensation. Our categorization system may be helpful in dealing with this question. For instance, the largest owner in a firm characterized by comfort with direct control in Panel A in figure 2 is significantly less affected than an owner in the direct control loss group is. In particular, our analysis can identify firms which incur no direct or likely control loss and, thus, may have weaker claims for being entitled to compensation.

A promising extension of the present analysis is to investigate whether firms that incur a direct or likely control loss behave differently from other firms in our sample. This question is indirectly addressed in Bennedsen and Nielsen (2003), who show that firms with dual class shares and a high degree of disproportional ownership structures create less firm value (measured by Tobin's Q) than other firms. Since firms incurring a direct or likely control loss do belong to this group, we conjecture that affected firms in general create less firm value than other firms. However, the value effects of dual class shares differ across countries and legal regimes, making it difficult to provide strong conclusions about the effect of a BT-rule on firm value within the European Union.

\section{Notes}

1. There are no firms with dual class shares in Belgium and Portugal. All EU countries were analysed except Greece, Holland and Luxembourg, due to a lack of data. 
2. Throughout this paper we define the group of large owners as all owners possessing more than 10 pct. of the votes in a given corporation.

3. For a full description of this data and the original sources we refer to Faccio and Lang (2002).

4. The Danish data were obtained from Greens, which publish an annual survey of the 5,000 largest Danish companies, while the Swedish data originates from SIS Ägarservice, which publishes an annual book on quoted companies in Sweden.

5. Faccio and Lang (2002) also include Swedish firms, but they are fewer in number.

6. In Italy and the UK, disclosure levels are 2 and 3 pct. respectively.

7. The 11 Swedish firms with dual class shares that have different voting structures than 10 to 1 are included in the general analysis in Section 4.

8. We have chosen a BT-rule of 75 pct. because this level is proposed in the Winter Report. However, our analysis is easily repeated for any other threshold values.

9. When reporting the number of firms in each group, those Swedish firms which could not be illustrated in figure 1 due to different voting structures are included, making the total number of firms 185 .

10. Figure 2 and the following figures are based on Tables A1 to A3 from our previous working paper (Bennedsen and Nielsen, 2003), which can be downloaded from www.cebr.dk. These tables identify all firms in our sample and catagorize them according to the terminology developed above.

11. See also Bennedsen and Nielsen (2003) for an analysis of the consequences of disproportionality.

12. Note once again that the identity of these firms can be found in the tables from our previous working paper, downloadable at www.cebr.dk.

\section{References}

Barca, F. \& Becht, M. (2001). Control of Corporate Europe, Oxford: Oxford, University Press.

Becht, M. (2002). "Corporate Takeover Defenses in Europe." Presentation at the ECGO Session on The Future of Corporate Takeovers in Europe at the Federation of European Securities Exchanges' 6th European Financial Markets Convention, Brussels, May 31.

Bebchuck, L. \& Hart, O. D. (2002). A Threat to Dual-Class Shares, Financial Times, May 31.

Bennedsen, M. \& Nielsen, K. M. (2003). “The Proportionality Principle.” Working Paper, Copenhagen Business School and Centre for Economic and Business Research (www. cebr.dk).

Berglöf, E. \& Burkart, M. (2003). "Break-Through" in European Takeover Regulation, Economic Policy, 18(36). Bolton, P. (2002). "Should the EU Adopt the Winter Proposals? Presentation at the ECGO Session on The Future of Corporate Takeovers in Europe at the Federation of European Securities Exchanges' 6th European Financial Markets Convention, Brussels, May 31.

Faccio, M. \& Lang, L. H. P. (2002). "The Ultimate Ownership of Western European Corporations.” Journal of Financial Economics. 65(3).

Gurgler, K. (2001). Corporate Governance and Economic Performance, Oxford: Oxford University Press.

Jensen, M. C. (2002). "Should the EU Adopt the Winter Group Proposals?" Presentation at the ECGO Session on The Future of Corporate Takeovers in Europe at the Federation of European Securities Exchanges' 6th European Financial Markets Convention, Brussels, May 31.

La Porta, R., Lopez-de-Silanes, F. \& Shleifer, A. (1999). “Corporate Ownership Around the World.” Journal of Finance. 54(2).

Mayer, C. (2002). "Should the EU Adopt the Winter Group Proposals?" Presentation at the ECGO Session on The Future of Corporate Takeovers in Europe at the Federation of European Securities Exchanges' 6th European Financial Markets Convention, Brussels, May 31.

Pagano, M. (2002). “Curing Symptom or Disease?” Presentation at the ECGO Session on The Future of Corporate Takeovers in Europe at the Federation of European Securities Exchanges' 6th European Financial Markets Convention, Brussels, May 31.

Winter Report. (2002). "Report of the High Level Group of Company Law Experts on Issues Related to Takeover Bids.” Brussels, January 2002. 